KAganga: Jurnal Pendidikan Sejarah dan Riset Sosial Humaniora

Volume 2, Nomor 1, Juni 2019

e-ISSN : 2598-4934

$p$-ISSN : 2621-119X

DOI : https://doi.org/10.31539/kaganga.v2i1.627

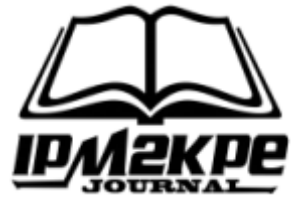

\title{
UPAYA MENINGKATKAN HASIL BELAJAR PESERTA DIDIK DALAM MATA PELAJARAN SEJARAH MELALUI METODE PEMBELAJARAN SORT CARD (SORTIR KARTU)
}

\author{
Zurmaneli Susanti \\ SMAN 1 Ranah Batahan Pasaman Barat \\ susantizurmaneli@gmail.com
}

\begin{abstract}
ABSTRAK
Tujuan penelitian ini adalah untuk mendeskripsikan dan mendapatkan informasi tentang upaya meningkatkan hasil belajar peserta didik dalam mata pelajaran Sejarah melalui Metode Pembelajaran Sort Card (Sortir Kartu) di Kelas XII IPS 3 SMA N 1 Ranah Batahan Kabupaten Pasaman Barat. Penelitian ini merupakan penelitian tindakan kelas. Prosedur penelitian meliputi perencanaan, tindakan, observasi dan refleksi. Data penelitian dikumpulkan dengan menggunakan lembar observasi dan ulangan harian. Data dianalisis dengan menggunakan persentase. Hasil belajar peserta didik dari siklus I ke siklus II. Hasil belajar peserta didik pada siklus I adalah 56.15 (Cukup) meningkat menjadi 84.04 (Baik) dengan peningkatan sebesar $27.89 \%$. Berdasarkan hasil penelitian dan pembahasan yang telah dikemukakan, maka dapat disimpulkan bahwa Metode Pembelajaran Sort Card (Sortir Kartu) dapat meningkatkan hasil belajar peserta didik dalam mata pelajaran Sejarah sub Proklamasi Kemerdekaan Indonesia di SMA N 1 Ranah Batahan .
\end{abstract}

Kata Kunci: Hasil Belajar, Metode Pembelajaran Sort Card (Sortir Kartu)

\begin{abstract}
The purpose of this study is to describe and obtain information about efforts to improve student learning outcomes in History subjects through Sort Card Learning Methods in Class XII IPS 3 SMA N 1 Ranahan Batahan, West Pasaman Regency. This research is a classroom action research. Research procedures include planning, action, observation and reflection. Research data was collected using observation sheets and daily tests. Data were analyzed using percentages. Learning outcomes of students from cycle I to cycle II. The learning outcomes of students in the first cycle were 56.15 (sufficient), increasing to 84.04 (good) with an increase of $27.89 \%$. Based on the results of the research and discussion that have been put forward, it can be concluded that the Sort Card Learning Method can improve the learning outcomes of students in the subjects of the History of the Indonesian Proclamation of Independence in N 1 High School Batahan.
\end{abstract}

Keywords: Learning Outcomes, Sort Card Learning Method 


\section{PENDAHULUAN}

Berhasilnya pelaksanaan suatu pendidikan, khususnya di sekolah, salah satunya ditentukan oleh kegiatan belajar mengajar yang dilakukan. Kegiatan belajar mengajar ditentukan oleh kemampuan guru dalam melaksanakan pembelajaran. Pembelajaran akan berhasil apabila seorang guru mampu berperan sebaik mungkin sebagai pendidik, fasilitator, motivator dan innovator. Artinya, pembelajaran akan menjadi berhasil apabila guru mampu menjadi guru yang profesional.

Penentu keberhasilan suatu pembelajaran pada dasarnya juga tergantung kepada peserta didik. Dalam pembelajaran, peserta didik dituntut untuk memiliki motivasi yang tinggi, aktif dan berpartisipasi dalam setiap proses belajar yang diikuti.

Kecenderungan dewasa ini untuk kembali pada pemikiran bahwa anak akan belajar lebih baik jika lingkungan diciptakan alamiah. Belajar akan lebih bermakna jika anak mengalami apa yang dipelajarinya bukan mengetahuinya. Pembelajaran yang berorientasi pada target penugasan materi terbukti berhasil dalam kompetisi mengingat jangka pendek, tetapi gagal dalam membekali anak memecahkan persoalan dalam kehidupan jangka panjang, dan itulah yang terjadi di kelas-kelas sekolah kita.

Model pembelajaran Sejarah yang terdapat dalam buku pelajaran Sejarah perlu diperkaya dengan model-model lain yang memberi nuansa baru, dan dapat meningkatkan kompetensi komunikasi peserta didik.
Selama ini model pembelajaran kurang menantang peserta didik, terutama gaya belajar yang monoton sehingga tidak memancing kreativitas peserta didik. Masalah yang paling menonjol dikalangan peserta didik khususnya pelajaran Sejarah, yang terasa sulit untuk dimengerti yakni berkaitan dengan penguasaan materi Sejarah tentang konsep-konsep terdapat di dalam ilmu Sejarah. Kenyataan ini yang akan menunjukkan adanya suatu komponen belajar mengajar belum mampu memberikan hasil yang memuaskan sesuai dengan pencapaian susunan itu sendiri. Kenyataan di atas mengharuskan pembelajaran Sejarah dilakukan secara intensif. Namun ada kesan yang berkembang di masyarakat bahwa mata pelajaran Sejarah merupakan mata pelajaran yang sangat susah dan momok bagi peserta didik sehingga hasil belajar peserta didik terhadap pelajaran Sejarah tergolong rendah. Dalam hal ini dibutuhkan pembenahan serius dalam pembelajaran Sejarah.

SMA N 1 Ranah Batahan adalah salah satu sekolah yang memiliki peserta didik yang mempunyai kemampuan yang beragam. Oleh karena itu, perlu ada pendekatan pembelajaran yang memungkinkan peserta didik atau peserta didik untuk memahami pelajaran sehingga pengetahuan yang diperolehnya dapat bertahan lama. Dan salah satu diantaranya adalah model pembelajaran yang memperhatikan keragaman individu peserta didik yaitu model pembelajaran Metode Pembelajaran 
Sort Card (Sortir Kartu) . Kondisi seperti di atas, dialami oleh peserta didik kelas XII IPS 3 SMA N 1 Ranah Batahan Kabupaten Pasaman Barat. Berdasarkan hasil ulangan harian yang dilakukan guru bidang studi Sejarah pada sekolah tersebut diperoleh informasi bahwa hasil belajar Sejarahpeserta didik di kelas tersebut tergolong rendah. Hal ini disebabkan karena peserta didik kurang mampu mengaitkan antara materi yang diajarkan dengan situasi dunia nyata peserta didik atau dalam kehidupan sehari-hari. Selain itu, juga dikarenakan penyajian materi Sejarah yang masih monoton dan membosankan sehingga peserta didik kurang tertarik belajar Sejarah. Dalam situasi demikian, peserta didik menjadi bosan karena tidak adanya dinamika, inovasi, kreativitas, dan peserta didik belum dilibatkan secara aktif sehingga guru sulit mengembangkan atau meningkatkan pembelajaran agar benar-benar berkualitas. Dengan penerapan Metode Pembelajaran Sort Card (Sortir Kartu) diharapkan mampu membantu peserta didik dalam memahami konsep yang mereka pelajari dan membantu mereka menemukan kaitan antar konsep. Hal ini penting bagi peserta didik dalam mempelajari bidang studi Sejarah. Sehingga dengan penerapan MetodePembelajaran Sort Card (Sortir Kartu) diharapkan dapat meningkatkan aktivitas peserta didik dan hasil belajar peserta didik, serta guru tidak lagi menjadi pusat pembelajaran. Guru hanya akan menjadi fasilitator dan mengontrol aktivitas belajar peserta didik dalam proses pembelajaran. Dengan penerapan Metode Pembelajaran Sort Card, maka diharapkan pelajaran Sejarah menjadi bidang studi yang disenangi, sehingga pada akhirnya akan meningkatkan aktivitas dan hasil belajar Sejarahpeserta didik. Oleh karena itu berdasarkan latar belakang di atas, dengan mengacu pada strategi eksporitori, penulis akan melakukan penelitian dengan judul yaitu, meningkatkan hasil belajar Sejarah melalui Metode Pembelajaran Sort Card (Sortir Kartu) di Kelas XII IPS 3 SMA N 1 Ranah Batahan Kabupaten Pasaman Barat.

Berdasarkan studi pendahuluan yang dilakukan peneliti melalui hasil ulangan pertama mata pelajaran Sejarah Kelas XII IPS 3 dan hasil observasi, ditemukan bahwa hasil belajar peserta didik Kelas XII IPS 3 masih rendah, khususnya dalam materi "Proklamasi Kemerdekaan Indonesia" dikarenakan: Kurangnya hasrat peserta didik untuk berhasil dalam belajar, kurangnya semangat, keinginan, dan kebutuhan peserta didik dalam belajar, peserta didik belum menyadari pentingnya materi yang disampaikan oleh guru, ingkungan untuk belajar kurang kondusif.

Hasil pengolahan nilai ulangan peserta didik dalam pembelajaran Sejarah khususnya di Kelas XII IPS 3 pada semester I tahun ajaran 2018/2019, ditemukan fenomena bahwa hasil pembelajaran Sejarah khususnya yang berkaiatan dengan Proklamasi Kemerdekaan Indonesia. Rata-rata hasil belajar yang diperoleh oleh peserta didik masih banyak yang berada di bawah KKM. Berdasarkan 
pengolahan hasil belajar peserta didik maka jumlah peserta didik yang tuntas hanya sebanyak 4 orang dengan persentase $13.29 \%$. Sedangkan jumlah peserta didik yang tidak tuntas adalah sebanyak 25 orang dengan persentase $86.21 \%$.

Berdasarkan permasalahan yang telah dijelaskan diatas yaitu rendahnya hasil belajar peserta didik dalam pembelajaran Sejarah khususnya materi yang berkaitan tentang "Proklamasi Kemerdekaan Indonesia", maka peneliti menggunakan salah satu alternatif metode yang dapat menstimulus peserta didik untuk berpartisipasi secara aktif dalam proses pembelajaran, sehingga dapat meningkatkan motivasi peserta didik dalam belajar. Metode tersebut adalah Metode Pembelajaran Sort Card (Sortir Kartu).

Pembelajaran dengan model

Sort Card merupakan kegiatan kolaboratif yang bisa digunakan untuk mengajarkan konsep penggolongan, sifat, fakta tentang suatu obyek, atau mengulang informasi. Gerakan fisik yang dilakukan peserta didik dapat membantu untuk memberi energi kepada kelas yang telah letih. Model pembelajaran ini mengajak peserta didik untuk belajar aktif dan bertujuan agar peserta didik mempunyai jiwa kemandirian dalam belajar serta menumbuhkan daya kreativitas. Model pembelajaran Sort Card atau menyortir kartu adalah model pembelajaran yang sangat sederhana yang terdiri dari kartu induk dan kartu rincian yang berisikan materi yang akan disampaikan pendidik kepada peserta didik.

Rendahnya hasil belajar peserta didikmerupakan akibat dari banyak faktor diantaranya yaitu sarana dan parasarana berupa media pembelajaran yang kurang memadai, minat serta motivasi peserta didik rendah yang menyebabkan peserta didik kurang aktif dalam mengikuti kegiatan belajar mengajar, Metode mengajar guru masih menggunakan Metode yang kurang bervariasi dan kurang sesuai. Untuk mengatasi hal tersebut perlu diupayakan langkahlangkah yang dapat dilaksanakan baik oleh peserta didik maupun guru. Guru hendaknya mengemas proses belajar mengajar dengan Metode yang tepat dan menarik dalam penyajiannya. Salah satu langkahnya adalah menggunakan Metode variasi dan bantuan alat peraga. Salah satu Metode yang di gunakan yaitu Metode Pembelajaran Sort Card (Sortir Kartu) (Walker, 2012).

Belajar merupakan tindakan dan perilaku peserta didik yang kompleks, sebagai tindakan, maka belajar hanya dialami oleh peserta didik sendiri. Peserta didik adalah penentu terjadi atau tidak terjadinya proses belajar. Proses belajar terjadi karena peserta didik memperoleh sesuatu yang ada di lingkungan sekitar. Lingkungan yang dipelajari oleh peserta didik adalah keadaan alam, benda-benda, hewan, tumbuh-tumbuhan, manusia atau hal-hal yang akan dijadikan bahan belajar (Hariyanto, 2015).

Belajar adalah proses mencari, memahami, menganalisis suatu keadaan sehingga terjadi perubahan perilaku, dan perubahan tersebut tidak 
dapat dikatakan sebagai hasil belajar jika disebabkan oleh karena pertumbuhan atau keadaan sementara. (Syaifuddin Iskandar, 2008)

Belajar secara umum, dapat diartikan sebagai proses perubahan prilaku akibat interaksi individu dengan lingkungannya. Sedangkan menurut Winkel (dalam Riyanto, 2012) belajar adalah suatu aktivitas mental/psikis yang berlangsung dalam interaksi aktif dengan lingkungan, yang menghasilkan perubahan-perubahan dalam pengetahuan-pemahaman,ketrampilan dan nilai sikap. Perubahan itu bersifat secara relatif konstan dan berbekas.

Menurut Gagne belajar merupakan kecendrungan perubahan pada diri manusia yang dapat diperhatikan selama proses pertumbuhan. Hal ini dijelaskan kembali oleh Gagne (dalam Riyanto, 2012) bahwa belajar merupakan suatu peristiwa yang terjadi di dalam kondisi-kondisi tertentu yang dapat diamati, diubah dan di kontrol.

\section{METODE PENELITIAN}

Jenis penelitian ini adalah penelitian tindakan. Menurut Zuriah, (2004) penelitian tindakan menekankan kepada kegiatan (tindakan) dengan mengujicobakan suatu ide ke dalam praktek atau situasi nyata dalam skala mikro yang diharapkan kegiatan tersebut mampu memperbaiki, meningkatkan kualitas dan melakukan perbaikan social. Esensi penelitian tindakan terletak pada adanya tindakan dalam situasi yang alami untuk memecahkan permasalahan-permasalahan prasktis atau meningkatkan kualitas praktis.
Penelitian tindakan yang dilakukan adalah penelitian tindakan kelas (PTK). Penelitian tindakan kelas ini terdiri atas empat tahapan dalam tiap siklusnya. Diantaranya: 1) perencanaan, 2) tindakan, 4) observer, dan 4) refleksi.

Model penelitian tindakan yang digunakan adalah model Stephen Kemmis dan Mc. Taggart. Mengadopsi dari Suranto (2000) model ini menggunakan sistem spiral yang dimulai dari rencana, tindakan, pengamatan, refleksi dan perencanaan kembali yang merupakan dasar untuk suatu ancang-ancang pemecahan masalah. Peneliti menggunakan model ini karena dianggap paling praktis dan aktual.

Untuk menganalisis tingkat keberhasilan atau persentase keberhasilan peserta didik dalam hal Hasil Belajar setelah proses belajar mengajar setiap putarannya dilakukan dengan cara mengkalkulasikan hasil pengamatan terhadap Hasil Belajar pada setiap akhir putaran. Analisis ini dihitung dengan menggunakan statistik sederhana yaitu:

Untuk menilai hasil belajar peserta didik Peneliti melakukan penjumlahan nilai yang diperoleh atas pengamatan terhadap hasil belajar peserta didik, yang selanjutnya dibagi dengan jumlah peserta didik yang ada di kelas tersebut. Perolehan rataRata Hasil Belajar dapat dirumuskan: $\bar{X}=\frac{\sum X}{\sum N}$

Dengan :

$\bar{X} \quad=$ Nilai rata-rata

$\Sigma X=$ Jumlah semua nilai hasil belajar peserta didik 
$\Sigma \mathrm{N}=$ Jumlah peserta didik

Kriteria keberhasilan

Untuk melihat peningkatan hasil belajar peserta didik dari satu pertemuan ke pertemuan selanjutnya, dan dari siklus I ke siklus II digunakan persentase. Menurut Yanuar (2005: 45) adapun kategori penilaian

$\begin{array}{ll}76 \%-100 \% & \text { Baik } \\ 51 \%-75 \% & \text { Cukup } \\ 26 \%-50 \% & \text { Kurang } \\ 0 \%-25 \% & \text { Tidak }\end{array}$

Apabila rata-rata peserta didik telah diatas 78 maka pendekatan ini dikatakan berhasil.

\section{HASIL DAN PEMBAHASAN Siklus Pertama}

Siklus pertama dalam penelitian tindakan ini dilaksanakan sebanyak 2 kali pertemuan. Berikut ini uraian masing-masing pertemuan dan materi untuk setiap pertemuan pada siklus I.

Selanjutnya untuk hasil belajar peserta didik pada siklus I diperoleh hasil dengan menggunakan Metode Pembelajaran Sort Card (Sortir Kartu) sebagai berikut:

Tabel 1. Hasil Pengamatan Terhadap Hasil belajar peserta didik Pada Siklus I

\begin{tabular}{lccc}
\hline No & Hasil Belajar & Jumlah & Persentase \\
\hline 1 & Tuntas & 10 & 34.48 \\
2 & Tidak Tuntas & 19 & 65.52 \\
\hline Sumber: Pengolahan data ulangan harian \\
peserta didik \\
Berdasarkan tabel diatas, \\
dapat diketahui bahwa hasil belajar \\
peserta didik dalam mata pelajaran \\
Sejarah. Hal ini terlihat banyak \\
jumlah peserta didik yang tidak \\
tuntas. Jumlah peserta didik yang
\end{tabular}

tidak tuntas pada siklus I adalah sebanyak 19 orang dengan persentase (65.52\%). Sedangkan jumlah peserta didik yang tuntas hanya sebanyak 10 orang atau sebesar (34.48\%). Sementara itu, skor rata-rata hasil belajar peserta didik untuk siklus I adalah $56.15 \%$.

Untuk lebih jelasnya grafik hasil belajar peserta didik dapat diamati pada diagram di bawah ini :

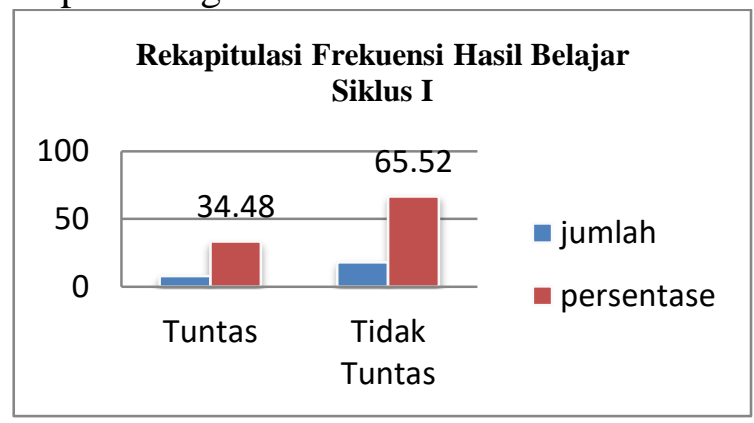

Rekapitulasi Frekuensi Hasil belajar peserta didikPada Siklus I

Berdasarkan diagram diatas terlihat bahwa persentase tertinggi terdapat pada jumlah peserta didik yang tidak tuntas. Selain itu, pada diagram diatas dapat kita mengamati bahwa rata-rata capaian hasil belajar peserta didikmasih di bawah standar yang telah ditetapkan atau masih di bawah KKM. Untuk itu, di perlukan lanjutan pelaksanaan pembelajaran dengan menggunakan Metode Pembelajaran Sort Card (Sortir Kartu) pada sisklus 2.

\section{Siklus kedua}

Siklus kedua dalam penelitian tindakan ini dilaksanakan sebanyak 2 kali pertemuan. Selanjutnyauntuk hasil belajar peserta didik pada siklus II diperoleh hasil dengan menggunakan model pembelajaraan 
Metode Pembelajaran Sort Card (Sortir Kartu) sebagai berikut:

Tabel 2. Hasil Pengamatan Terhadap Hasil belajar peserta didik Pada Siklus II

\begin{tabular}{|c|c|c|c|}
\hline $\mathrm{O}$ & $\begin{array}{l}\text { Hasil } \\
\text { Belaiar }\end{array}$ & $\begin{array}{l}\mathrm{J} \\
\text { umlah }\end{array}$ & $\begin{array}{c}\text { Pers } \\
\text { entase }\end{array}$ \\
\hline & & 2 & 86.2 \\
\hline & Tuntas & 5 & 1 \\
\hline & $\begin{array}{l}\text { Tidak } \\
\text { Tuntas }\end{array}$ & 4 & $9^{13.7}$ \\
\hline & Jumlah & 2 & 100 \\
\hline & $\begin{array}{l}\text { lber: Pen } \\
\text { rta didik }\end{array}$ & han & ulangan \\
\hline
\end{tabular}

Berdasarkan tabel diatas, dapat diketahui bahwa hasil belajar peserta didik dalam mata pelajaran Sejarah sudah tinggi. Hal ini terlihat banyak jumlah peserta didik yang tuntas. Jumlah peserta didik yang tuntas pada siklus II adalah sebanyak 25orang dengan persentase $(86.21 \%)$. Sedangkan jumlah peserta didik yang tidak tuntas hanya sebanyak 4 orang atau sebesar (13.79\%). Sementara itu, skor rata-rata hasil belajar peserta didik untuk siklus II adalah82.41.

Untuk lebih jelasnya grafik hasil belajar peserta didik dapat diamati pada diagram di bawah ini :

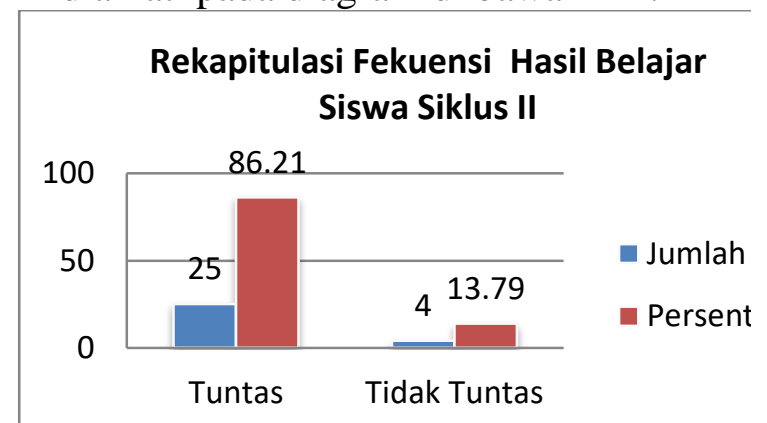

Rekapitulasi Frekuensi Hasil belajar peserta didikPada Siklus II
Berdasarkan diagram diatas terlihat bahwa persentase tertinggi terdapat pada jumlah peserta didik yang tuntas. Selain itu, pada diagram diatas dapat kita mengamati bahwa rata-rata capaian hasil belajar peserta didik sudah berada diatas standar yang telah ditetapkan atau sudah berada di atas KKM. Untuk itu, tindakan pelaksanaan pembelajaran dengan menggunakan model pembelajaraan Sort Card (Sortir Kartu) tidak perlu dilanjutkan pada siklus berikutnya.Perkembangan hasil belajar peserta didikpada siklus I dan siklus II dapat dilihat pada data berikut ini.

Tabel. 3 Perkembangan Rata-rata Hasil belajar peserta didik antara Siklus I dan Siklus II

\begin{tabular}{|c|c|c|c|}
\hline No & Siklus & $\begin{array}{l}\text { Rata-rata Hasil } \\
\text { belajar peserta didik }\end{array}$ & Kateg \\
\hline 1 & I & 63.09 & Cukup \\
\hline 2 & II & 82.41 & Baik \\
\hline
\end{tabular}
perkembangan rata-rata hasil belajar peserta didik pada siklus I dan siklus II dapat disimpulkan bahwa terdapat peningkatan hasil belajar peserta didik , dimana rata-rata hasil belajar peserta didik pada siklus I adalah 63.09meningkat 82.41menjadi pada siklus II. hal ini dapat dilihat bahwa terdapat peningkatan sebesar 19.32dalam hal hasil belajar peserta didik .

Untuk lebih jelasnya tentang hasil belajar peserta didik dapat 


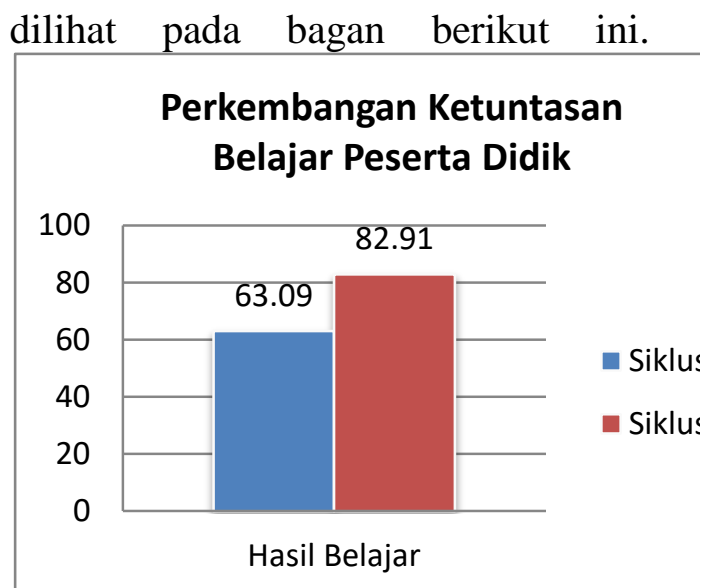

Perkembangan Hasil belajar peserta didik (Perbandingan Siklus I dan Siklus II)

Selanjutnya, jumlah peserta didik yang tuntas setelah dilaksanakan pembelajaran dengan menggunakan Metode Pembelajaran Sort Card (Sortir Kartu) meningkatkan. Berikut ini tabel perkembangan tingkat ketuntasan peserta didik.

Tabel. 4 Perkembangan Tingkat Ketuntasan Hasil belajar peserta didik Siklus I dan Siklus II

\begin{tabular}{cccc}
\hline No & Kriteria & Siklus I & Siklus II \\
\hline 1 & Tuntas & 4 & 25 \\
2 & Tidak Tuntas & 25 & 4 \\
\hline
\end{tabular}

Perkembangan tingkat ketuntasan peserta didik juga dapat dilihat dalam bagan berikut ini.

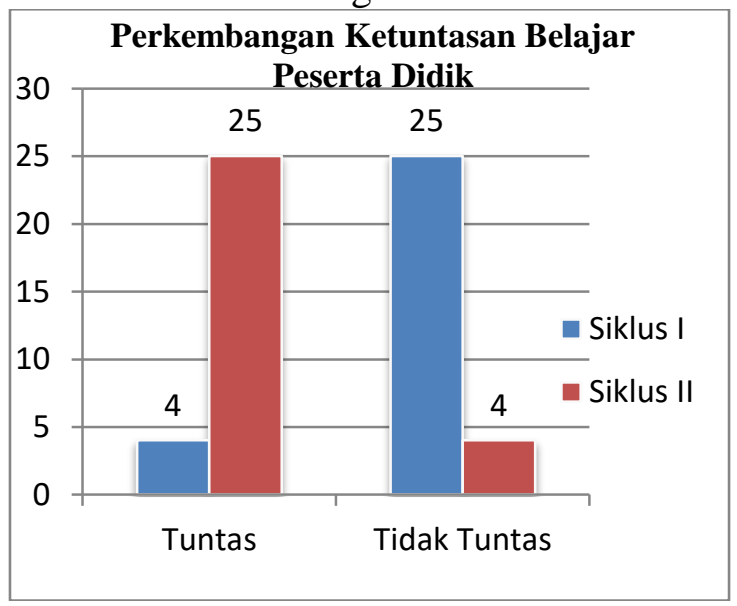

Perkembangan Tingkat Ketuntasan peserta didik(Perbandingan Siklus I dan Siklus II)

Dari hasil analisis data hasil belajar peserta didik pada siklus II dapat dilihat bahwa hasil belajar peserta didik pada setiap siklus mengalami peningkatan dan telah mencapai target ditentukan yaitu 75 , maka penelitian ini dihentikan dan tidak di lanjutkan siklus berikutnya.

Hasil belajar yang bagus adalah harapan setiap peserta didik guru dan orang tua. Hasil belajar merupakan tujuan akhir dilaksanakannya kegiatan pembelajaran di sekolah. Hasil belajar dapat ditingkatkan melalui usaha sadar yang dilakukan secara sistematis mengarah kepada perubahan yang positif yang kemudian disebut dengan proses belajar. Akhir dari proses belajar adalah perolehan suatu hasil belajar peserta didik. Hasil belajar peserta didik di kelas terkumpul dalam himpunan hasil belajar kelas (Winata, 1997).

Berdasarkan analisis terhadap hasil belajar peserta didikdalam mata pelajaran Sejarah sub Menemukan unsur-unsur instrinsik tes drama dan menyimpulkan isi drama melalui pembacaan dramadengan menggunakanMetode Pembelajaran Sort Card (Sortir Kartu) dapat disimpulkan bahwa hasil belajar peserta didik mengalami peningkatan bila dibandingkan dengan hasil yang dicapai sebelum menggunakan model ini. Hasil belajar peserta didik dalam mata pelajaran Sejarahsub Proklamasi Kemerdekaan Indonesia sebelum menggunakan model ini masih banyak yang rendah dan banyak yang belum tuntas. Rata-rata hasil belajar 
peserta didik berada di bawah KKM. Namun setelah penggunaan model ini, hasil belajar peserta didik dalam mata pelajaran Sejarahsub Proklamasi Kemerdekaan Indonesiamenjadi meningkat.

Berdasarkan hasil pengolahan data sebelum model ini digunakan, ditemukan bahwa hasil belajar peserta didik hanya 4 orang peserta didik yang tuntas tetapi setelah menggunakan Metode Pembelajaran Sort Card (Sortir Kartu) ini rata-rata hasil belajar peserta didik dari siklus I ke siklus II meningkat menjadi dengan peningkatan sebesar 19.32.

Berdasarkan uraian diatas, dapat disimpulkan bahwa Metode Pembelajaran Sort Card (Sortir Kartu) dapat meningkatkan hasil belajar peserta didik dalam mata pelajaran Sejarah sub Proklamasi Kemerdekaan Indonesia melalui pembacaan dramadi SMA N 1 Ranah Batahan. Salah satu Metode pembelajaran yang sering digunakan guru adalah Metode Pembelajaran Sort Card (Sortir Kartu) . Metode Pembelajaran Sort Card (Sortir Kartu) merupakan Metode yang paling sederhana dibandingkan dengan Metode-Metode belajar lainnya.

Pembelajaran dengan model Sort Card merupakan kegiatan kolaboratif yang bisa digunakan untuk mengajarakan konsep penggolongan, sifat, fakta tentang suatu obyek, atau mengulang informasi. Gerakan fisik yang dilakukan peserta didik dapat membantu untuk memberi energi kepada kelas yang telah letih. Model pembelajaran ini mengajak peserta didik untuk belajar aktif dan bertujuan agar peserta didik mempunyai jiwa kemandirian dalam belajar serta menumbuhkan daya kreativitas. Model pembelajaran Sort Card atau menyortir kartu adalah model pembelajaran yang sangat sederhana yang terdiri dari kartu induk dan kartu rincian yang berisikan materi yang akan disampaikan pendidik kepada peserta didik.

\section{SIMPULAN}

Berdasarkan hasil penelitian dan pembahasan yang telah dikemukakan pada bab sebelumnya, maka dapat disimpulkan bahwa dapat disimpulkan bahwa Metode Pembelajaran Sort Card (Sortir Kartu) dapat meningkatkan hasil belajar peserta didik dalam mata pelajaran Sejarah sub Proklamasi Kemerdekaan Indonesia di SMA N 1 Ranah Batahan.

Hasil belajar peserta didik dari siklus I ke siklus II mengalami peningkatan. Hasil belajar peserta didik pada siklus I adalah 63.09 (Cukup) meningkat menjadi 82.41 (baik) pada siklus II dengan peningkatan sebesar $19.32 \%$.

\section{DAFTAR PUSTAKA}

Hariyanto. (2012). Penelitian Tindakan Kelas. Jakarta: Gaung Persada Press

Hariyanto. (2015). Implementasi Belajar dan Pembelajaran. Bandung: Rosdakarya

Walker. (2012). Model Desain Sistem Pembelajaran. Jakarta: Dian Rakyat. 
2019. Kaganga: Jurnal Pendidikan Sejarah dan Riset Sosial Humaniora 2 (1): 58-67

Putra. W \& Rosita. (1997). Konsep dan Makna Pembelajaran. Jakarta : Alfabeta.

Zuriah. (2004). Konsep-Konsep dan Teknik Supervisi Pendidikan Dalam Rangka Pengembangan Sumber Daya Manusia. Jakarta: Rineka Cipta. 